\title{
Developing self-management and teamwork using digital games in 3D simulations
}

José M. Cela-Ranilla, Francesc M. Esteve-Mon, Vanessa Esteve-González, Mercè Gisbert-Cervera Rovira i Virgili University

\begin{abstract}
Emerging technologies are providing opportunities for designing new learning environments, especially environments in which students can learn by putting their skills into practice. Knowledge about the development of these experiences needs to be accumulated and processed so that they can be integrated effectively into training programmes. In this study we describe how transferable skills such as self-management and teamwork have been developed by 70 Spanish students of Education and Marketing. The learning experience comprised a serious game designed in a 3D simulation environment. For the analysis, two analytical rubrics were taken as references. Descriptive statistics and non-parametric tests such as Mann-Whitney $U$ and Spearman rho were conducted for comparison and correlation analysis. Our results showed that the students performed well and had a positive perception of the suitability of using the simulation environment for the development of transferable skills. We also found that women performed better than men in activities involving teamwork, especially communication tasks.
\end{abstract}

\section{Introduction}

Learning environments based on three-dimensional (3D) simulations are suitable platforms for enabling students to put their knowledge into practice in an integrated way. Part of this knowledge is a set of skills that can be implemented in a wide range of personal and professional situations. These so-called transferable skills are an important component of university curricula that has emerged from the construction of the new European Higher Education Area (EHEA). The construction of didactic methods for developing and evaluating these skills represents a challenge for the majority of higher education (HE) institutions.

Emerging technologies are providing excellent opportunities for designing training environments in which learners can develop professional activities that require them to act, take decisions and/or make constructions collaboratively. Environments based on advanced technology enable simulations of professional situations to be created in which students can practice their skills safe in the knowledge that any errors they make will have no repercussions in real life. This safe and controlled process enables the students' learning activities to be analysed, evaluated and reoriented. The simulations can transform an academic activity into a professional environment by controlling certain parameters that allow educational objectives to be achieved. It may be said that the strategies for simulating the professional environment create an educative virtuality when they are also accompanied by a pedagogical strategy that is intended to meet specific teaching objectives.

Serious games (technological game-based applications with an educational purpose as well as an entertainment one) via 3D simulations are useful for putting learners in situations where they can acquire transferable competencies. The great potential of digital games does not lie in their gaming characteristics but in the fact that their attributes can be integrated into a process that gears itself towards learning. These attributes translate into certain educational affordances of virtual worlds (Girvan \& Savage, 2010), that emerge from learning theories related to communal construction, such as active collaboration, active engagement, knowledge construction, flexibility, motivation, competition, immersion and interaction with the environment.

Technological trends in virtual worlds are moving towards using game engines that integrate multiplatform games. These allow the use of applications to edit documents and facilitate the integration of augmented reality to lay the virtual world over the real world. As a social space, the future of virtual worlds can be improved with more realistic communication to add emotion sensing and natural language understanding to the avatar's expressions. 
In the words of Ibáñez et al. (2011, p.8), "virtual worlds open the door to a new way of learning". Managing these new teaching environments is also more complex. In this direction, several recent studies have connected these technological environments with specific teaching processes, such as the concept of identity and presence (Schifter, Ketelhut \& Nelson, 2012) and learning styles (Sancho, Moreno-Ger, Fuentes-Fernández \& Fernández-Manjón, 2009).

The few similar experiments in the Spanish educational context have so far been limited to the precollege levels (Barlam, Masalles \& Pinya, 2010) and the development of highly technical skills in fields such as medicine (López-Cano, Rodríguez-Navarro, Rodríguez-Baeza, Armengol-Carrasco \& Susín, 2007) and molecular chemistry (Cuesta-López \& Romero-Santacreu, 2013). This experiment covers new ground and includes the development of general and transversal key competencies at the university level. This novel situation drives us to develop research studies from a descriptive approach, which in comparative or relational terms could serve as the basis for further studies developed from an experimental perspective.

This study specifically comprises two components: a 3D simulation game, and transferable skills (teamwork and self-management). Our aim is to describe an experience in which Spanish university students acquired these skills by developing a game-based learning process in a 3D simulation environment. We describe our experience by developing the components that integrate the process as a whole: the technological environment, the transferable skills (teamwork and self-management), the pedagogical strategy, and the assessment process. We also present results to evaluate the academic performance of the students.

With the transferable skills of self-management and teamwork as references, the following research questions are posed as a guide for our research work:

Q.1. How did the university students interact within the technological environment?

Q.2. Were there any differences in students' performances based on gender or academic domain?

Q.3. What were the students' perceptions about using the 3D simulation environment in their experience of acquiring the transferable skills?

Q.4. How well did the students perform in academic terms at the end of the process?

\section{D digital games}

The Horizon Report (Johnson, Adams Becker, Estrada \& Freeman, 2014) states that augmented reality and game-based learning will soon become part of our future. This future is also taking shape in higher education institutions with proposals of more open and adaptable models for diversifying teaching/learning processes (Berlanga, Peñalvo \& Sloep, 2010). Identifying the educational effectiveness of technological learning environments is a common task for researchers in the current knowledge society but this task is becoming particularly difficult in the face of increasing technological complexity. We are currently observing the emergence of environments that promote actions in simulated real situations with added game components.

Technological advances enable the transformation of simple games and digital games into serious digital games when they intentionally adopt educational components. According to Hirumi, Appelman, Rieber and Van Eck (2010), a proper balance between education and entertainment is necessary in order to optimize game-based learning. It is difficult to find a standard categorization of digital games. In fact, there are many definitions (Kirriemuir, 2004) and classifications of educational games and serious games and their relationships to virtual worlds and simulations (Aldrich, 2009; Sawyer \& Smith, 2008). Games have become more involved in terms of graphics, complexity, interaction and narrative.

In the last two decades, several game classifications have been developed in accordance with diverse criteria. The first taxonomies were linked to the type of game (Herz, 1997; Kirriemuir, 2004), though we stress those that have an educational component as the reference (de Freitas, 2006) and those that depend on cognitive functions and skills (O’Brien, Lawless \& Schrader, 2010). Aldrich (2009) presented the relationship between games, simulations and virtual worlds as points along a continuum. As these are highly interactive virtual environments, the key lies in the potential of their technical characteristics and the educational activities that are conducted within this environment. From the technological perspective, 
virtual worlds have the potential to capture attention, motivate and stimulate desired interaction, allowing students to take control of the environment. The system invites students to learn and they become the focus of the educational process.

Our research work involves the concept of the serious digital game and how it can be managed in an intentional educative way. Two key themes are common to the development of games for education: the desire to harness the motivational power of games in order to make learning fun and the belief that learning by doing in games such as simulations provides a powerful learning tool. Linking the theoretical background and our pedagogical strategy, we take pedagogical approaches that go from the learning activity theory (de Freitas \& Oliver, 2006) specifically located in higher education contexts (Whitton, 2009) to Kirriemuir (2004), who recognized that game play can support the valuable development of skills such as strategic thinking, planning, communication, the application of numbers, negotiating skills, group decision-making and data-handling. Dalgarno and Lee (2009) explain the potential learning benefits of 3D virtual learning environments (VLE) when compared to tasks enabled by the 2D environment and propose a model of learning in 3D VLEs that incorporates their characteristics and learning affordances.

These skills can be developed in virtual worlds by combining game-like qualities within an open world in which the users/players construct landscapes, buildings and environmental objects and control the appearance of their in-world personifications or avatars. Virtual worlds are simple to use and have collaboration facilities, 3D attractiveness and a high immersive sensation for the user. Some experts have added educational weight in terms of an effective educative principle (Spector, 2001), curricular principles (Chang, Peng \& Chao, 2010), design steps (Pivec, Dziabenko \& Schinnerl, 2003) and key points for practitioners, educators and stakeholders (de Freitas, 2006).

\section{Self-managing learning and developing teamwork skills}

In recent years the acquisition of skills, especially those known as transferable skills, has become a central issue in educational debate. Transferable skills are those that are common to the majority of professions, contribute to valued outcomes for societies and individuals, and help individuals meet important demands in a wide range of contexts (OECD, 2005). These generic skills or competencies are important for adapting to change, promoting democratic citizenship, and remaining informed and involved in society (European Communities, 2007). In the present study, we analysed two of these skills: teamwork and self-management.

Teamwork is considered one of the most effective ways of improving performance in educational and professional contexts. Teamwork improves the quality of learning, increases productivity and promotes the creation of knowledge. Over the last 20 years, it has become an important building block of organisational effectiveness (Wilson, Goodman \& Cronin, 2007).

The Secretary's Commission on Achieving Necessary Skills (SCANS) report (1991) defined this competence as the capacity to work cooperatively with others and to contribute to the group with ideas, suggestions, and effort. The Association of American Colleges and Universities (2007) placed this competence in the group of essential learning outcomes for the twenty-first century. Teamwork and collaborative learning combine two key goals: learning to work and to solve problems in the company of others, and sharpening one's own understanding by listening seriously to the insights of others, especially those with different backgrounds and life experiences.

Teaming and collaboration mean cooperative interaction between two or more individuals working together to solve problems, create novel products, or learn and master content (Burkhardt et al. , 2003). If we observe learning models based on teamwork, we can see that their effectiveness can be conditioned by aspects (Van Woerkom \& Croon, 2009) such as awareness of team and task (Fransen, Kirschner \& Erkens, 2011) or by those defined by Salas, Sims and Burke (2005), i.e. team leadership, team orientation, mutual performance monitoring, backup behaviour (the ability to anticipate other team members' needs) and adaptability, and mechanisms to support and coordinate the construction of shared mental models.

The skill of self-management (also called personal management) on the other hand, is the capacity to accurately assess one's own knowledge, skills and abilities; to set well-defined and realistic personal 
goals, to monitor progress towards the attainment of goals, and to motivate oneself by achieving goals (SCANS, 1991). It is the ability to set learning-related goals, to plan to achieve those goals, to independently manage time and effort, and to assess the quality of learning and any product of the learning experience (Burkhardt et al., 2003). The term self-directed learning is also often used to refer to this concept. This can be more focused on the educational process and encompass both individual and social dimensions (Song \& Hill, 2007). Academic self-regulation refers to students' proactive efforts to regulate their own academic learning and performance metacognitively, motivationally, and behaviourally (Zimmerman \& Martínez-Pons, 1992).

According to the DeSeCo project (OECD, 2005), individuals need to be able to take responsibility for managing their own lives, to situate their lives in the broader social context and to act autonomously. Similarly according to the Ministry of Education of Singapore (2010), students can manage themselves effectively if they have the capacity to manage their own emotions. They should be self-motivated, exercise discipline and display strong goal-setting and organizational skills. Finally, the Partnership for $21^{\text {st }}$ Century Skills (2011) defined self-management as the ability to: set goals with tangible and intangible success criteria; balance tactical and strategic goals; utilise time and manage workload efficiently; and monitor, define, prioritise and complete tasks without direct oversight.

As we can see, these competencies are complex constructs that can be integrated by multiple knowledge, abilities and attitudes. It will be necessary to operationalise their definitions by describing their elements and learning objects (digital online educational resources) in order to develop and assess them according to their complexity (Simpson, 2003). In fact these competencies are described through four dimensions of an analytical rubric that has already been validated in a Spanish research and development project called Simul@ (2012). For the present research, we define the rubrics of these competencies with these dimensions: a) Teamwork: (1) Identity and (2) Communication; and b) Self-management: (1) Planning, (2) Organisation, (3) Development and (4) Assessment.

\section{The 3D learning environment}

We set up a complex learning environment based on the foundations of active learning, learning by doing, and learning by competencies. All these approaches are related to processes linked to socio-constructivist perspectives ranging from situated learning theories (Lave \& Wenger, 1991) to social theories such as expansive learning and the transfer of development (Tuomi-Gröhn \& Engeström, 2003). According to Gredler (2004), virtual environments create particular settings and attempt to draw the participant into that setting. The idea of construction in a specific context of practice implies the incorporation of an active learning perspective (Meyers \& Jones, 1993; Prince, 2004).

According to Bonwell and Eison (1991), a pedagogical strategy based on active learning should largely be targeted towards higher-order activities (analysis, synthesis and evaluation) in which students should explore their own attitudes and values, and should provide the opportunity to support reflection on both the content learned and the learning process (Savery \& Duffy, 1996). Such strategies are also aligned with a set of good practices in undergraduate education that have already been formulated by Chickering and Gamson (1991) to encourage contact between students and faculty by: developing reciprocity and cooperation among students, encouraging active learning, emphasizing time on task and respecting diverse talents and ways of learning.

In view of these considerations, the didactic sequence proposed in this study is based on project-based learning, which integrates game elements in order to promote challenge and competition and enhance performance. This method is a systematic student-centred process (Grant, 2002) in which participants acquire and transfer learning by developing an observable activity, alone or in pairs, by planning and anticipating actions that lead towards an end product that can be supervised and evaluated by an expert (Proulx, 2004).

After observing the above didactic implications (de Freitas \& Oliver, 2006; Kirriemuir, 2004; Whitton 2009), we now describe the design of the learning environment-the pedagogical strategy used to implement the training activity. The training activity was developed using the Opensim multi-user virtual environment. This environment was integrated (Kemp, Livingstone \& Bloomfield, 2009) with a Moodle learning-management system via the Simulation Linked Object Oriented Dynamic Learning Environment 
(SLOODLE). SLOODLE enables the communication process between objects in the virtual world and assignments in Moodle.

The Opensim environment had a central island that contained the general instructions for the whole activity, a chat tool and 3D objects previously created for the construction of the project. Each group was assigned its own space/island in which to build its project from existing resources or by creating new ones and to carry out certain activities set by the teacher related to the transversal competencies that would later be evaluated.

The teacher proposed a training activity in which students in groups of three were required to develop/construct a project within the 3D simulated environment. Students of education were asked to construct a school Olympics and students of marketing were asked to construct a stand for a product at a trade fair.

- School Olympics (students of education). Students conducting this project were asked to organise a five-day school Olympics comprising a programme of sports events and social activities that encompassed all the sports offered at the school. The students worked on content related to (1) safety, supervision, medical matters and healthcare; and (2) dissemination, advertising and the management of economic resources.

- Trade fair (students of marketing). Students conducting this project were asked to take part in a four-day fair to present and promote a new product and/or service. The students worked on content related to (1) creativity, including the design and preparation of promotional material for the fair; (2) finance, including preparation of the programme and the programme budget; and (3) logistics and infrastructure, including the reservation and design of the fair's layout.

The whole training activity proposed by the teacher was structured into a didactic sequence that, in the 3D simulation environment, comprised the four phases illustrated in Figure 1 (Cela-Ranilla et al., 2011).

Phase 1 Preliminary: This phase comprised a three-hour face-to-face session with the teacher in charge of the project and the technician responsible for providing technical support to both teacher and students throughout the duration of the project. At this session the students were introduced to the environment, the project was explained, and diagnostic information was gathered. The phase concluded with the formation of groups.

Phase 2 Planning: In this phase the students developed specific activities in order to accumulate points that they could exchange for resources at the end of the phase. The activities were related to the specific content and had several characteristics: organisation, elaboration, anticipation and explanation/ justification (see table 1). This phase was conducted before the groups began constructing their project on their own island.

Table 1

Activities developed during the Planning phase

\begin{tabular}{|c|c|}
\hline School Olympics (students of Education) & Trade fair (students of Marketing) \\
\hline $\begin{array}{l}\text { AEd.1 Specify the group's objectives and tasks. } \\
\text { AEd.2 Identify the basic items of a first aid kit. } \\
\text { AEd.3 Locate the key sites: points of access, } \\
\text { sporting event locations, loudspeaker system, } \\
\text { advertising, etc. } \\
\text { AEd.4 Define the strategy for finding and } \\
\text { managing sponsors. } \\
\text { AEd.5 Draw up a basic budget for income and } \\
\text { expenditure. } \\
\text { AEd.6 Determine the contents of publicity and } \\
\text { advertising messages. } \\
\text { AEd.7 Devise the full programme of events } \\
\text { (schedule, locations, resources, etc.). }\end{array}$ & $\begin{array}{l}\text { AMk.1 Specify the group's objectives and tasks. } \\
\text { AMk.2 Select the brand name as well as the logo and } \\
\text { slogan for the product. } \\
\text { AMk.3 Define the strategy and design the publicity. } \\
\text { AMk.4 Choose the type of professional event at which } \\
\text { the product will be presented. } \\
\text { AMk.5 Propose the budget for the presentation of the } \\
\text { new product or service. } \\
\text { AMk.6 Manage reservation of the sites to be used at } \\
\text { the fair location. } \\
\text { AMk.7 Design the arrangement and specific location of } \\
\text { the stand. }\end{array}$ \\
\hline
\end{tabular}


Phase 3 Development/construction: In this phase each group built its project by creating its own resources and using and managing the resources they had earned during the previous activities. Each group had two weeks to build their project on their island, during which time they were free to seek help from their teacher or technician.

Phase 4 Reporting: In this phase each group had 1 hour to present and defend their project, or island, before a committee of experts.

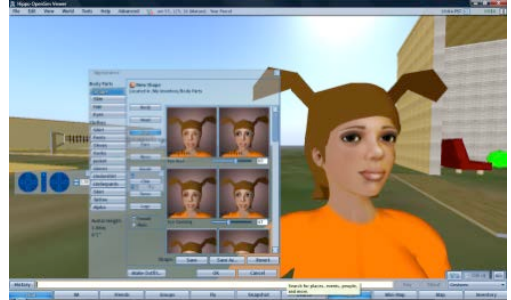

(a) Preliminary - Creating an avatar in a virtual world

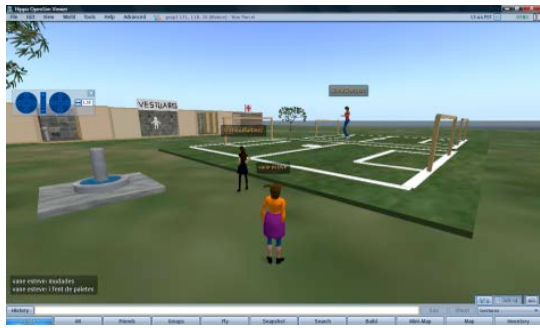

(c) Development/construction - Building the proposal

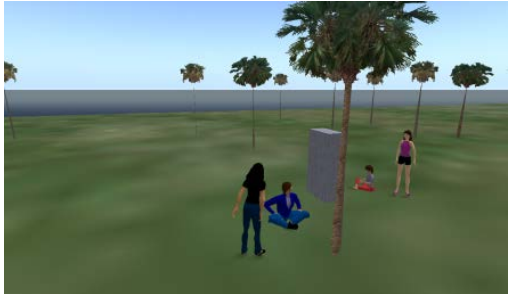

(b) Planning - Organising the project proposed by the group

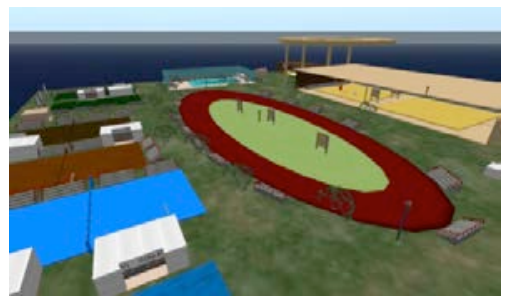

(d) Reporting - Presenting the final island

Figure 1. Four phases of the 3D simulation environment

Throughout the experience, the teacher assumed the roles of expert in the subject, designer of the teaching sequence, and student supervisor. Two other collaborators contributed to the project's technical design and helped the groups to carry out their activity.

\section{Assessment process}

The assessment model used in this paper is based on alternative assessment, which facilitates an evaluative judgment based on observations, promotes an evaluation that is focused on the student and the group, enables evaluators to create a story around the students, facilitates curricular action, and allows students to participate in their own evaluation (Mateo, 2000). The alternative assessment approach has several modalities. In our study we propose a model based on so-called performance assessment that requires students to demonstrate, build or develop a product or solution from defined conditions and standards (Rodriguez, 2000). This approach defines certain steps to develop: from Khattri and Sweet (1996), who propose structuring the evaluation tasks, applying prior information, building responses and explaining the process; and from Wren (2009), who propose defining the purpose, choosing the activity, and developing the scoring criteria.

One of the characteristics of performance assessment is its criterial nature. This kind of assessment requires accepted and validated criteria defined as a holistic or analytical rubric. This rubric is made up of a criterion-based scoring guide (Wiggins \& McTighe, 1998), also characterised by Palm (2008), who states that most definitions offered for performance assessment can be viewed as response-centred or simulation-centred.

Both skills and the corresponding dimensions (see table 2) were assessed using analytical rubrics developed and validated in the specific context of the Spanish research project Simul@ (2012). This validation process constituted a specific subproject aimed at adapting the competencies assessment 
process to the 3D learning environment. The rubrics were organised at various levels ranging from generic dimensions to specific elements.

Table 2

Evaluation rubrics

\begin{tabular}{|c|c|c|c|}
\hline COMPETENCIES & DIMENSIONS & ELEMENTS & INDICATORS \\
\hline \multirow{4}{*}{ 产 } & T1. Identity & $\begin{array}{l}\text { T1.1 Identification of objectives } \\
\text { T1.2 Knowledge of objectives } \\
\text { T1.3 Acting by objectives } \\
\text { T1.4 Team integration (sense of belonging) } \\
\text { T1.5 Role assumption } \\
\text { T1.6 Acting upon the assigned role } \\
\text { T1.7 Perception of adaptability needs } \\
\text { T1.8 Adaptability } \\
\text { T1.9 Implications with the team }\end{array}$ & \multirow{8}{*}{ 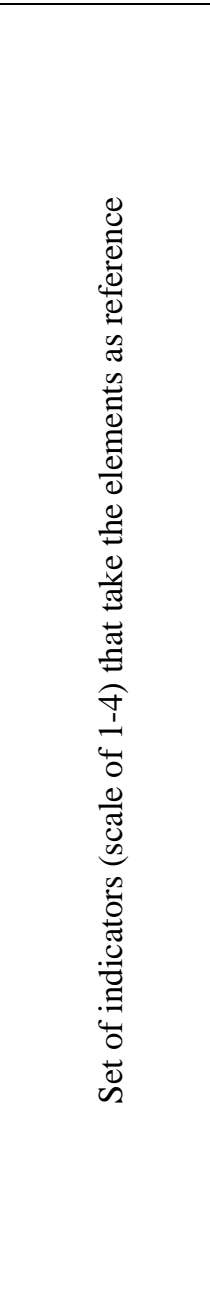 } \\
\hline & T2. Communication & $\begin{array}{l}\text { T2.1 External information search } \\
\text { T2.2 Internal information search } \\
\text { T2.3 Transmission of information } \\
\text { T2.4 Personal attitude }\end{array}$ & \\
\hline & T3. Implementation & $\begin{array}{l}\text { T3.1 Planning } \\
\text { T3.2 Decision making } \\
\text { T3.3 Execution of tasks }\end{array}$ & \\
\hline & T4. Regulation & $\begin{array}{l}\text { T4.1 Conflict resolution } \\
\text { T4.2 Negotiation } \\
\text { T4.3 Improvement }\end{array}$ & \\
\hline \multirow{4}{*}{ 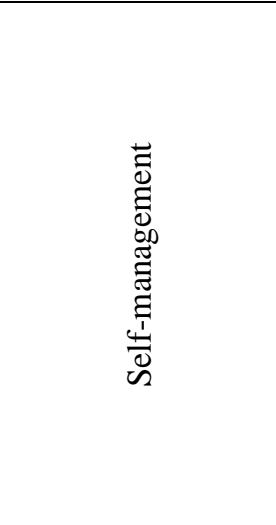 } & S1. Planning & $\begin{array}{l}\text { S1.1 Motivation } \\
\text { S1.2 Analysis of proposal } \\
\text { S1.3 Formulation of objectives } \\
\text { S1.4 Task planning }\end{array}$ & \\
\hline & S2. Organisation & $\begin{array}{l}\text { S2.1 Time management } \\
\text { S2.2 Assignment of responsibilities } \\
\text { S2.3 Assumption of responsibilities } \\
\text { S2.4 Estimation of resources } \\
\text { S2.5 Location /selection of resources }\end{array}$ & \\
\hline & S3. Development & $\begin{array}{l}\text { S3.1 Actions } \\
\text { S3.2 Monitoring }\end{array}$ & \\
\hline & S4. Assessment & $\begin{array}{l}\text { S4.1 Assessment criteria } \\
\text { S4.2 Improvement orientation }\end{array}$ & \\
\hline
\end{tabular}

To evaluate the students' transferable skills during the whole training activity, a recording system was established in which the evaluation rubrics, and specifically their elements, were taken as references. The information was gathered in two ways:

- One way was via the implementation of the activities defined in the Planning phase (see $\mathrm{O} 1$ in table 3). The results of these activities were registered on Moodle and evaluated by the teacher.

- The other way was via the interactions generated during the Planning and Development/construction phases in the virtual environment (chat, videos and images). These interactions were evaluated by the teachers and observers (researchers) who participated in the experience, also taking the rubric as reference (see $\mathrm{O} 2$ in table 3). Figure 2 illustrates how observers could score certain indicators. As we can see, the chat logs constitute the raw data that contain relevant information for estimating how well certain students performed with regard to a specific indicator expressed in the rubric. 


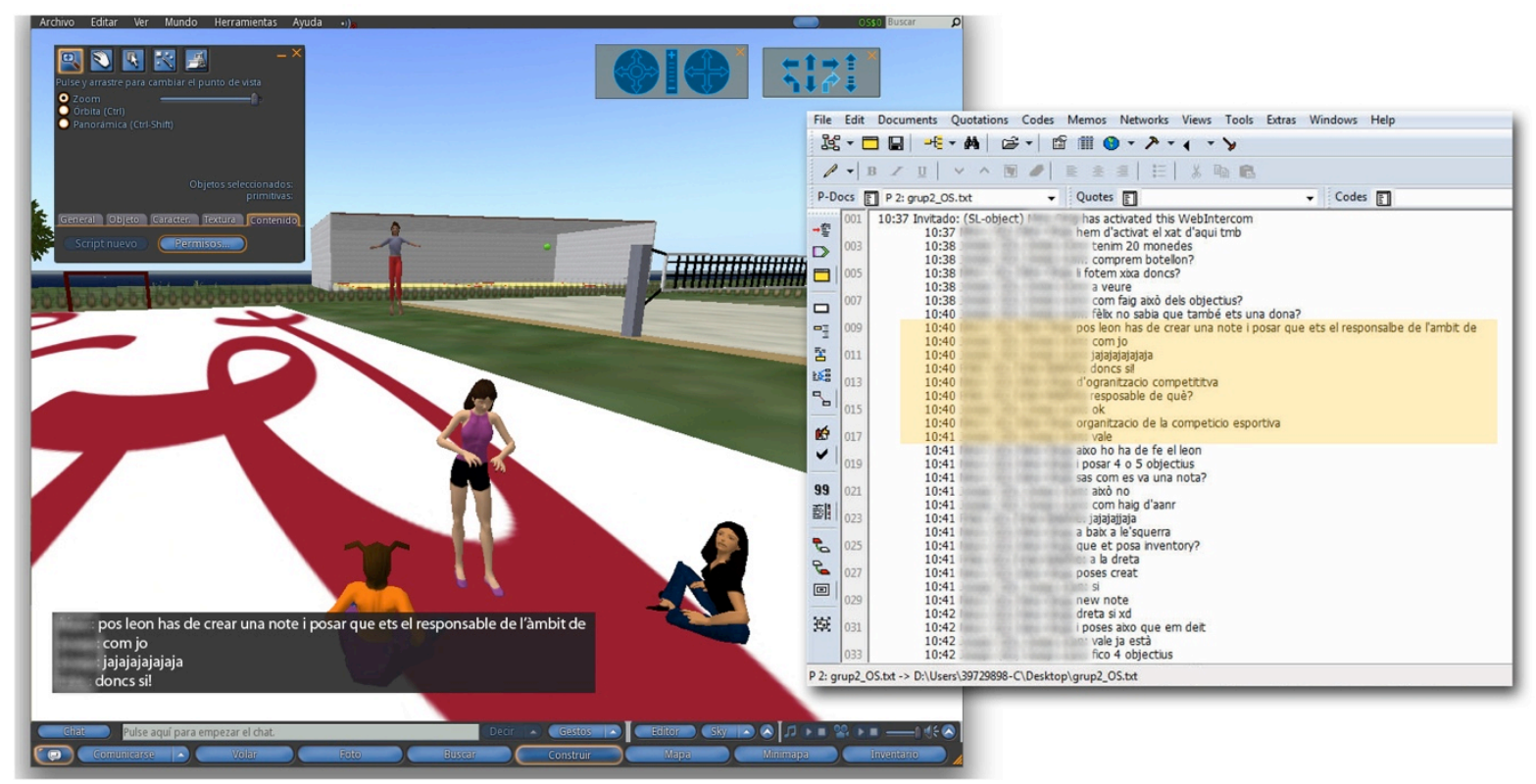

Figure 2. Observer scoring process

At the end of the process, the final project or island developed by each group was evaluated by observing the final construction in the island (see $\mathrm{O} 3$ in table 3). These islands were assessed (see figure 3) by six evaluators in accordance with the following three criteria: Organisation-the structural arrangement of the objects used in the 3D world; Variety of objects - the range of objects created and used on the island; and Relevance-the coherence and appropriateness of the project requirements. These criteria are used to provide an integrated evaluation of the result of each group's work. This evaluation responds to the project's academic objectives as well as to those involving use of the technological environment.

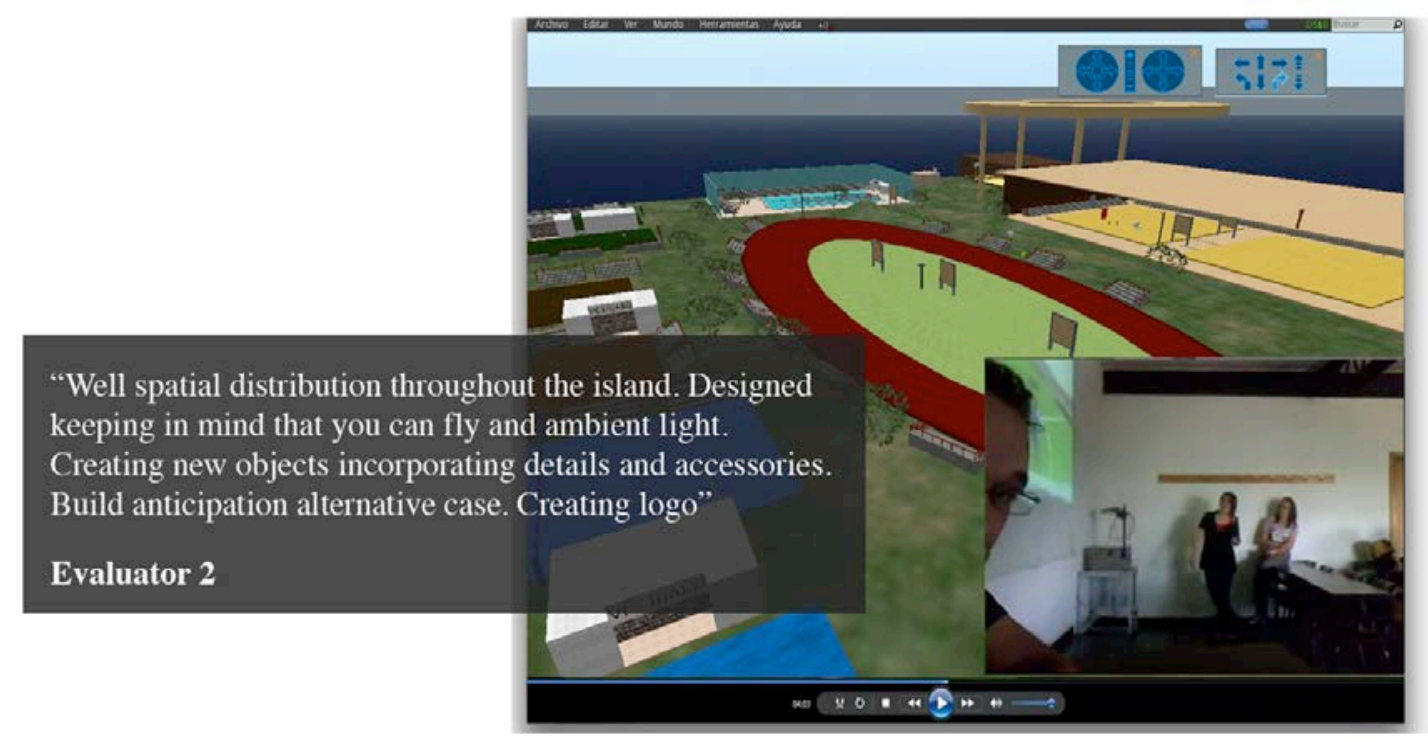

Figure 3. Presentations of final projects or islands

To further complement the evaluation process, at the end of the training activity the students were asked about their perceptions on using the 3D simulated environment for acquiring the two transversal competencies analysed (see $\mathrm{O} 4$ in table 3).

Evaluators of this concept were both participants and non-participants with a range of different profiles: the teacher responsible for the academic activity, the technician responsible for providing technical 
support to both teacher and students, and researchers of the Simul@ project (2012), who observed the whole process from a global perspective.

In summary, table 3 illustrates the general evaluation process for the experience. This will be reflected in the presentation of the results.

Table 3

General evaluation process

\begin{tabular}{|c|c|c|c|c|c|c|c|c|c|}
\hline \multirow{2}{*}{$\begin{array}{l}\text { Contents to } \\
\text { evaluate }\end{array}$} & \multirow{2}{*}{$\begin{array}{l}\text { Scoring } \\
\text { reference }\end{array}$} & \multirow{2}{*}{\multicolumn{2}{|c|}{ By observing }} & \multicolumn{4}{|c|}{ Phases } & \multirow{2}{*}{ Evaluators } & \multirow{2}{*}{ Procedure } \\
\hline & & & & $\mathrm{P}$ & $\mathrm{P}$ & $\mathrm{P}$ & $\mathrm{P}$ & & \\
\hline $\begin{array}{l}\text { Level of } \\
\text { competence }\end{array}$ & Rubric elements & $\begin{array}{l}\text { O1. } \\
\text { Activities } \\
\text { related to } \\
\text { each element } \\
\text { (see table } 1 \text { ) }\end{array}$ & $\begin{array}{l}\mathrm{O} 2 . \\
\text { Interactions } \\
\text { in the virtual } \\
\text { world }\end{array}$ & $\mathrm{X}$ & $\mathrm{X}$ & $\mathrm{X}$ & & $\begin{array}{l}\text { Teache } \\
\text { rs } \\
\text { Observ } \\
\text { ers }\end{array}$ & $\begin{array}{l}\text { Hetero- } \\
\text { evaluation }\end{array}$ \\
\hline $\begin{array}{l}\text { Quality of } \\
\text { project }\end{array}$ & $\begin{array}{l}3 \text { criteria: } \\
-\quad \text { Organisation } \\
\text { - Variety of } \\
\text { objects } \\
-\quad \text { Relevance } \\
\end{array}$ & O3. The final & oject or island & & & & $\mathrm{X}$ & $\begin{array}{l}\text { Teache } \\
\text { rs } \\
\text { Observ } \\
\text { ers }\end{array}$ & $\begin{array}{l}\text { Hetero- } \\
\text { evaluation }\end{array}$ \\
\hline $\begin{array}{l}\text { Students' } \\
\text { perceptions } \\
\text { on the use of } \\
\text { the } 3 D \\
\text { learning } \\
\text { environment }\end{array}$ & Rubric elements & O4. Students' & aluation & & & & $\mathrm{X}$ & $\begin{array}{l}\text { Student } \\
\mathrm{s}\end{array}$ & $\begin{array}{l}\text { Self- } \\
\text { perception }\end{array}$ \\
\hline
\end{tabular}

\section{Method}

As we mentioned in the introduction, we used descriptive methods and assessment techniques based on the performance assessment model. Data were collected by observation (participants and nonparticipants) and documentary analysis (video, chat, images and 3D object interactions).

The whole training activity conducted by the students was analysed by following the events that took place during the activity. This analysis was based on a triangular process comprising method, data and researchers. The methods used to collect the information were as follows: (a) mixed observation (participants and non-participants) from three types of evaluators (subject experts, technical support staff, and process supervisors); (b) documentary analysis of videos, chats and interactions that took place during the activity; and (c) student self-perception questionnaires taking as reference previously validated rubrics for the competencies analysed in this study (see table 2).

All the information gathered during the experiment was subjected to a process of codification, tabulation and statistical analysis. The data were analysed using SPSS V.18 statistical software.

\section{Participants and learning context}

Participants in the study were 70 bachelor and master students (72.9\% female and $27.1 \%$ male) with a mean age of $23.97(S D=6.24)$ from the education domain ( $87.1 \%$ degree in teacher training) and the business domain (12.9\% master in marketing management) during the 2010-11 academic year.

\section{Procedure}

The experiment was conducted during the second semester of the 2010-11 academic year. The training activity was developed by students over one month as part of the schedule defined in the formal curricula. The students were informed by the professor and the training activity within the 3D virtual world was mandatory for all students. They had unlimited access to the environment. On average, they were connected for 2 hours a day in the planning phase and from 3 to 5 hours a day in the construction phase. 


\section{Instruments}

Transferable skills

Data from both skills (teamwork and self-management) and the corresponding dimensions (see table 2) were gathered using two analytical rubrics developed and validated in the specific context of the Spanish research project Simul@ (2012). This validation process constituted a specific subproject aimed at adapting the competencies assessment process to the 3D learning environment. The rubrics were organized at different levels ranging from generic dimensions to specific indicators calculated on a scale of 1 to 4 (level 1 = deficient; level 2 = acceptable; level 3 = good; level 4 = excellent). This scale was recalculated to a range of $1-10$. For this new estimation, we used the following intervals: $0-2.5=$ level 1 ; $2.5-5=$ level 2; 5-7.5= level 3; 7.5-10= level 4. Examples of indicators in each rubric are as follows. With regard to Teamwork: T1.5 Role assumption: (1) he/she does not assume the role; (2) he/she assumes the role defined by others; (3) he/she assumes the role by considering his/her own capabilities; (4) he/she assumes his/her own role and promotes role assumption by other team members. With regard to Selfmanagement: S2.2 Assignment of responsibilities: (1) he/she does not assign tasks; (2) he/she assigns tasks with adequate criteria; (3) he/she assigns tasks by establishing priorities; (4) he/she assigns tasks by prioritizing and offering alternative tasks.

Final projects or islands

The various products or islands were assessed by measuring the three criteria explained earlier (Organization, Variety of Objects, and Relevance). Each criterion was assessed using an ad-hoc built tool consisting of a scale of 1 to 10 with an open space for qualitative comments to be provided by evaluators after observing both the final projects and the students' presentations.

\section{Students' perceptions on the use of the 3D learning environment}

To estimate the students' perceptions on using the 3D simulation environment in their learning experience of transferable competencies, we used a questionnaire in which the students indicated their perception according to the elements of the two competencies. This perception was valued as indifferent, negative or positive (codified by 0,1 and 2, respectively).

\section{Analysis design}

With regard to description of interaction with the technological environment (Q.1 and Q.2), we took the level of transferable competence as the dependent variable (DV) by analysing the differences between groups formulated in function of gender and academic subject. For this analysis we calculated descriptive statistics and two non-parametric tests: the independent samples Mann-Whitney $U$ test and the Spearman rho correlation analysis. To further develop the comparison between groups, we also present the differences in mean ranks between groups as a simple estimation that can serve as an effect size index (Green \& Salkind, 2008; Leech \& Onwuegbuzie, 2002). We used Q.3 to analyse the students' perceptions (DV) of using the simulator (IV), taking as reference the transferable competencies analysed in the study. Finally, we analysed the end result of the teaching activity (Q.4) by evaluating the quality of the project's end product (DV). To validate this product assessment, we calculated the standard deviation so as to determine the level of agreement between the six evaluators who participated in the assessment. Table 4 illustrates the analysis design devised to respond to the research questions.

Table 4

Analysis design and research questions

\begin{tabular}{|l|l|ll|}
\hline Q.1 & Level of competence (rubric elements) & $\begin{array}{l}- \\
-\end{array}$ & $\begin{array}{l}\text { Descriptive statistics } \\
\text { The Spearman rho correlation analysis }\end{array}$ \\
\hline Q.2 & Level of competence (rubric elements) & $\begin{array}{l}- \\
-\end{array}$ & $\begin{array}{l}\text { Independent samples Mann-Whitney } U \text { test } \\
\text { ranks) }\end{array}$ \\
\hline Q.3 & $\begin{array}{l}\text { Students' perception on the use of the 3D } \\
\text { learning environment }\end{array}$ & - & $\begin{array}{l}\text { Descriptive statistics } \\
\text { Percentile estimation }\end{array}$ \\
\hline Q.4 & The quality of the project's end product & - & $\begin{array}{l}\text { Descriptive Statistics } \\
\text { Standard deviation }\end{array}$ \\
\hline
\end{tabular}




\section{Results}

The two box plots show information about the sample distribution for the dimensions. These plots show that only the Assessment dimension presented symmetry around the median. The other dimensions presented negative asymmetry. When we took competence as the unit of analysis, we also observed a negative asymmetry for each of them. Figure 4 provides graphic information about the non-assumption of the normality condition of the whole sample for both competencies and its dimensions. This graphic view is confirmed by a later Kolmogorov-Smirnov analysis.

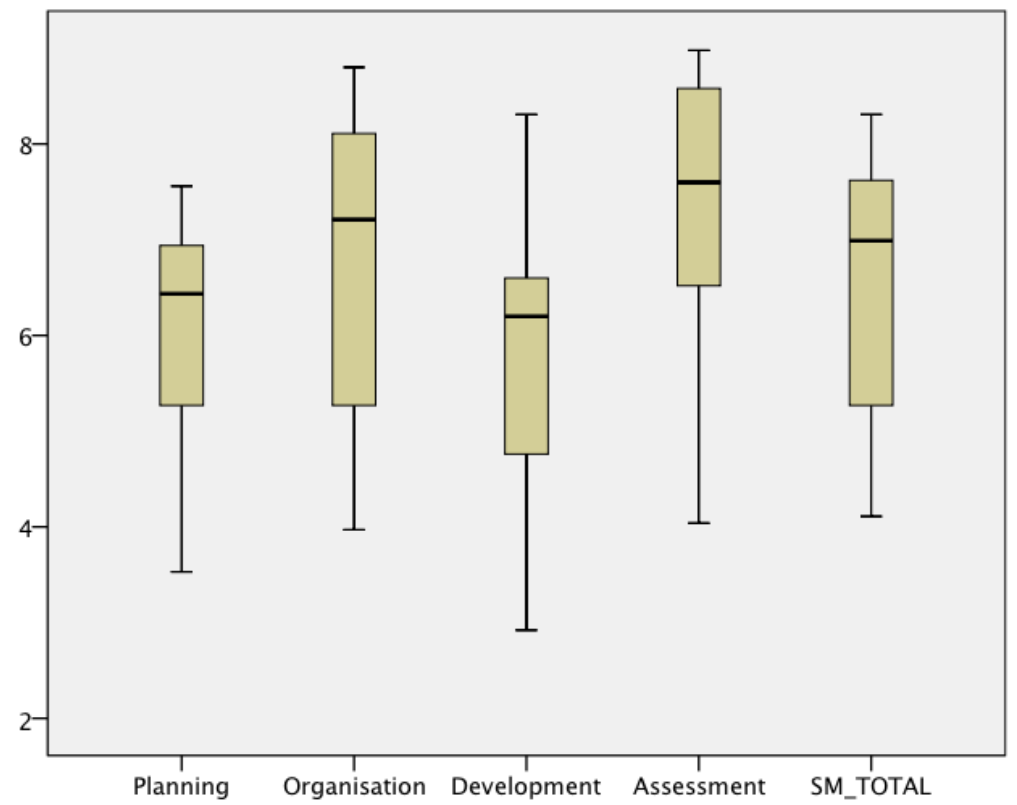

(a) Self-management $[\mathrm{SM}]$

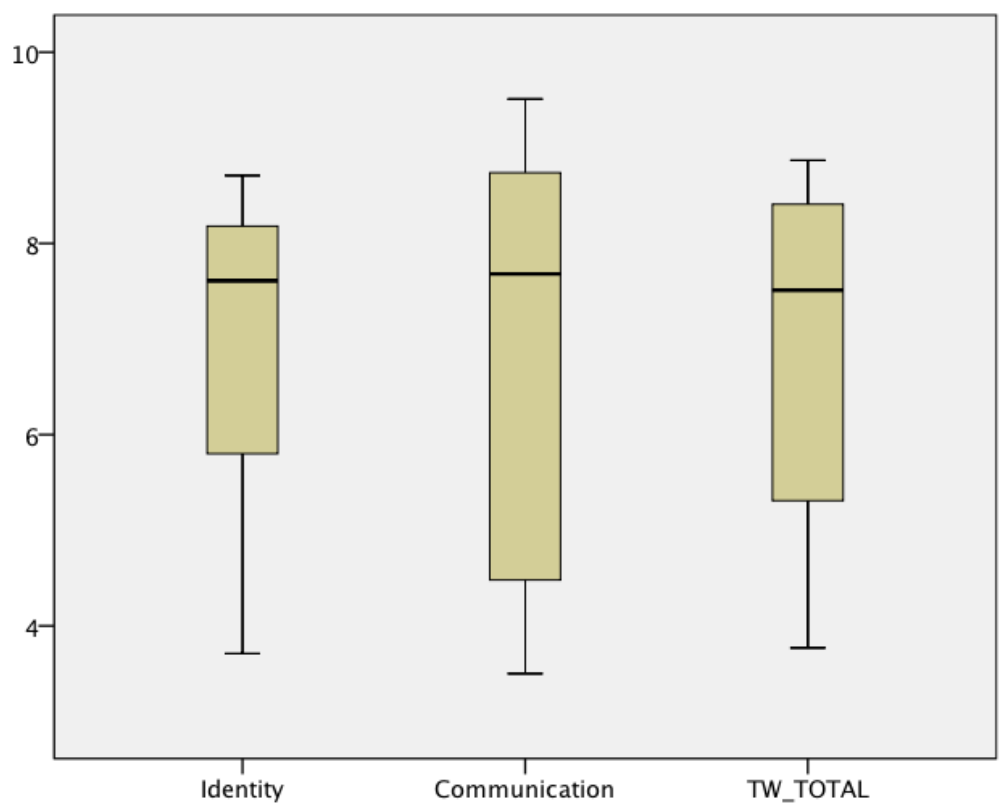

(b) Teamwork [TW]

Figure 4. Box plot of the distribution of competencies and its dimensions.

Figure 5 shows that the students developed a good level of performance with regard to self-management and teamwork. None of their dimensions reached the excellent level. Only the Assessment dimension ( $M$ 
$=7.46$ ) bordered the highest level. None of the other dimensions analysed presented values below the good level (Ms of between 5.88 and 7.05) (see correlations in Table 5).

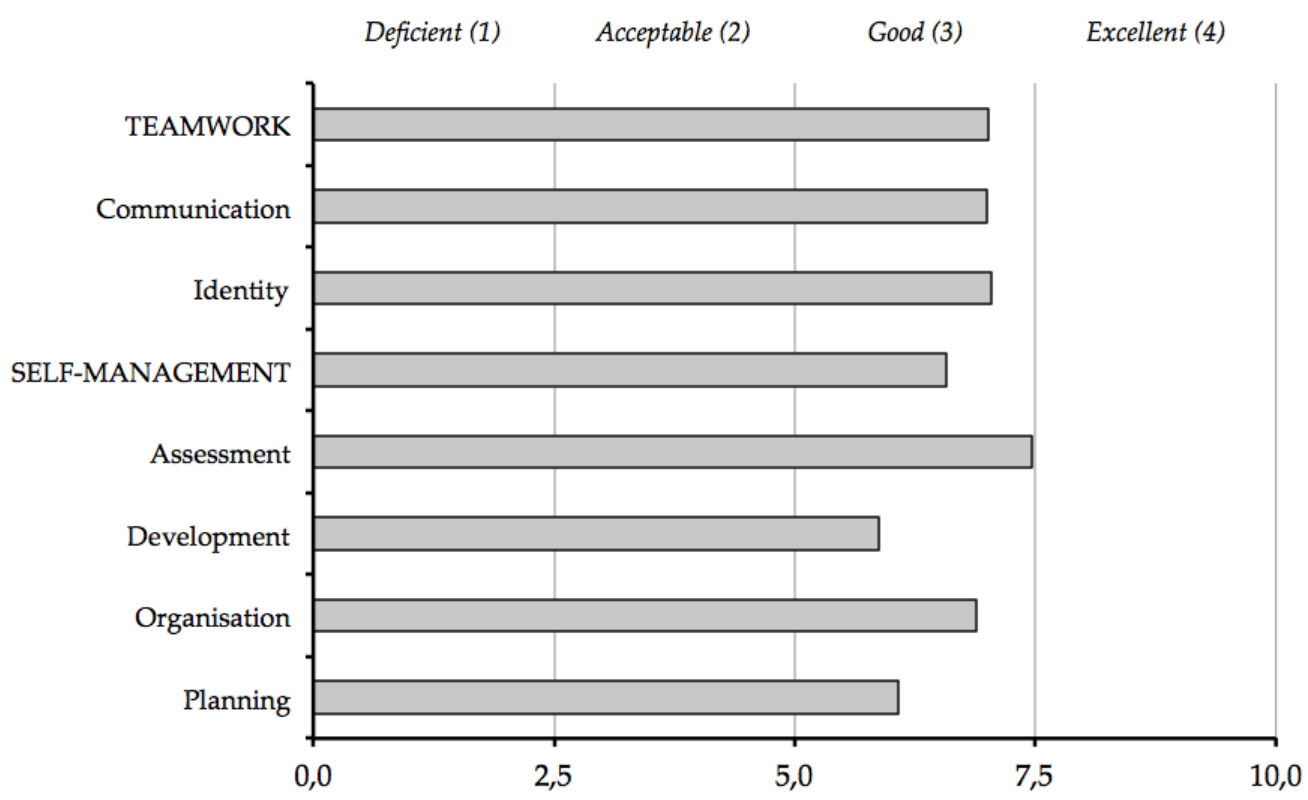

Figure 5. Mean scores of elements and dimensions in the sample

The correlation analysis (Table 5) shows that the dimensions that belong to the same skill presented a strong positive and significant intercorrelation. This was observed for both generic skills. The most striking observation derived from this analysis was the negative correlation (although this was not significant) between the Teamwork dimensions and some Self-management dimensions such as Identity, and especially Assessment.

Table 5

Correlation analysis

\begin{tabular}{lccccccccccc}
\hline & $\mathrm{N}$ & Mean & $\mathrm{SD}$ & 1 & 2 & 3 & 4 & 5 & 6 & 7 & 8 \\
\hline 1. Planning & 70 & 6.07 & 1.08 & 1 & & & & & & & \\
2. Organisation & 70 & 6.89 & 1.53 & $.861^{* *}$ & 1 & & & & & & \\
3. Development & 70 & 5.88 & 1.23 & $.863^{* *}$ & $.897^{* *}$ & 1 & & & & & \\
4. Assessment & 70 & 7.46 & 1.41 & $.809^{* *}$ & $.963^{* *}$ & $.823^{* *}$ & 1 & & & & \\
5. Identity & 70 & 7.05 & 1.46 & .146 & -.061 & .000 & -.133 & 1 & & & \\
6. Communication & 70 & 6.99 & 2.04 & $.269^{*}$ & .056 & .109 & -.084 & $.859^{* *}$ & 1 & & \\
7. TEAMWORK & 70 & 7.02 & 1.69 & .218 & -.013 & .060 & -.128 & $.938^{* *}$ & $.971^{* *}$ & 1 & \\
8. SELF- & 70 & 6.58 & 1.25 & $.914^{* *}$ & $.981^{* *}$ & $.933^{* *}$ & $.947^{* *}$ & -.023 & .092 & .030 & 1 \\
MANAGEMENT & & & & & & & & & & & \\
\hline
\end{tabular}

* Correlation is significant at the 0.05 level (2-tailed).

** Correlation is significant at the 0.01 level (2-tailed).

Table 6 shows that women performed statistically significantly better than men in activities that involved teamwork $(r=-0.24)$, especially in communication $(r=-0.26)$ tasks. Our results also show that education students presented significantly higher values than marketing students for all dimensions analysed. 
Table 6

Mann-Whitney $U$ tests with regard to gender and domain (education vs marketing)

\begin{tabular}{llccccc}
\hline \multirow{2}{*}{ SELF- } & & Mann- & Wilcoxon & \multicolumn{3}{c}{ Asymp. Sig. } \\
MANAGEMENT & variable & Whitney $U$ & $\mathrm{~W}$ & $\mathrm{Z}$ & (2-tailed) & r (effect size) \\
\hline \multirow{2}{*}{ Planning } & gender & 428 & 1754 & -0.746 & 0.455 & -0.09 \\
& domain & 33.5 & 78.5 & -4.229 & 0.000 & -0.51 \\
Organisation & gender & 403 & 1729 & -1.077 & 0.282 & -0.13 \\
& domain & 126 & 171 & -2.606 & 0.009 & -0.31 \\
Development & gender & 426.5 & 1752.5 & -0.767 & 0.443 & -0.09 \\
& domain & 14 & 59 & -4.580 & 0.000 & -0.55 \\
Assessment & gender & 407 & 1733 & -1.024 & 0.306 & -0.12 \\
\multirow{3}{*}{ TEAMWORK } & domain & 47 & 92 & -3.993 & 0.000 & -0.48 \\
& gender & 470 & 660 & -0.192 & 0.848 & -0.02 \\
Identity & domain & 0 & 45 & -4.825 & 0.000 & -0.58 \\
& gender & 329.5 & 1655.5 & -2.048 & 0.041 & -0.24 \\
Communication & domain & 61 & 1952 & -3.748 & 0.000 & -0.45 \\
& gender & 409 & 1735 & -0.998 & 0.318 & -0.12 \\
& domain & 71.5 & 1962.5 & -3.564 & 0.000 & -0.43 \\
& gender & 320 & 1646 & -2.178 & 0.029 & -0.26 \\
\hline
\end{tabular}

To analyse the end product of the process, we observed the final island designed by each group. The scores are presented in terms of mean values for three defined criteria: Organisation, Variety of Objects, and Relevance. We estimated the standard deviation in each criterion in order to verify the level of agreement of the evaluators.

Table 7

Statistics of the final project scores

\begin{tabular}{lcc}
\hline \multicolumn{1}{c}{ Assessment criteria } & Mean & SD \\
\hline Organisation & 7.78 & 0.922 \\
Variety of objects & 7.67 & 0.912 \\
Relevance & 7.69 & 0.880 \\
Total & 7.72 & 0.797 \\
\hline
\end{tabular}

Table 7 shows that all the standard deviation values were below 1.0, which suggests that the experts reported a high level of agreement. The islands designed obtained scores of above 7.5 on a scale of 1 to 10. All groups therefore performed very well in all criteria and also as a whole.

Figure 6 shows that the effect of the simulation on students' perception in both skills as a whole was mostly positive. The total amount of positive items reached $74.3 \%$ for Self-Management and $82.5 \%$ for Teamwork. However, it is interesting to note that Teamwork had almost $10 \%$ more positive items than Self-management. To further analyse these results, we also report on the dimensions in each skill. 


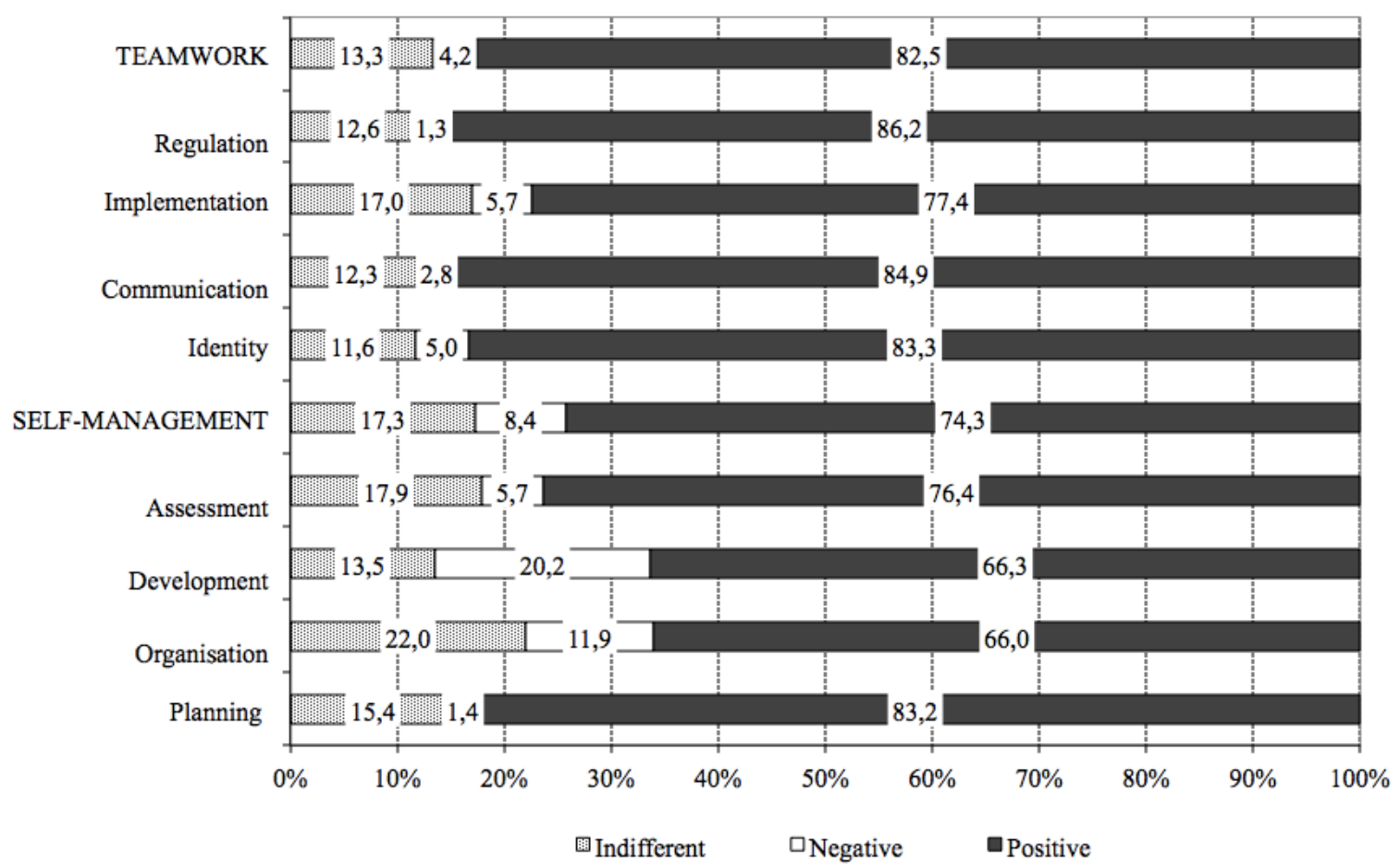

Figure 6. Perception of simulation effect in percentages

With regard to Self-management, the Assessment dimension (76.4\% positive) and especially the Planning dimension (83.2\% positive) presented the highest percentages of positive items. On the other hand, the Organization dimension presented $11.9 \%$ of negative items and the Development dimension presented the highest percentage of indifferent items (20.2\%). With regard to the Teamwork dimensions, the Implementation dimension presented the lowest percentage of positive items (77.4\%), with the other three dimensions attaining over $82 \%$ of positive items.

\section{Discussion}

The main aim of this paper is to describe an experience in the development of the transferable skills of self-management and teamwork using digital games within a 3D simulation environment. This discussion section is structured around the research questions posed in the introduction to this paper and answered according to the analysis design illustrated in table 4.

The first research question was to analyse how university students interact within the technological environment. According to the results obtained from the dimensions of the rubrics, the students developed a level of 3 (good) in a 1-4 scale of performance with regard to self-management and teamwork. If we were to take these good results with some caution, we could think that they were perhaps due to oversimplicity of the task the students were asked to complete or to the motivational aspect implied by working in a simulation environment. The degree of difficulty does not lend itself to much scepticism, however, since the task was set by the teacher and integrated into the curriculum during the course. Secondly, while the motivational aspect could be considered to increase the students' engagement with the task, this positive factor could be balanced by their feeling of insecurity when performing evaluable activities in an unfamiliar environment.

A reasonable interpretation of the results could be that the experience showed that the students were able to work autonomously to develop and present an end product. This should lead to some rethinking of teaching tasks: professors can concentrate their activities on tasks related to planning, creating and selecting resources, as well as monitoring student activity. We should therefore not be afraid to propose learning processes in this kind of environment. Today's students expect to be a part of teaching processes in which they can perform in a much more personalized manner. They feel comfortable when performing in an enjoyable way and in an academic setting oriented to building some artefact with real relevance. 
With regard to the second question, significant differences were found based on gender. Women performed better than men in activities that involve teamwork, especially communication tasks. Our results are in the same direction as those of Burke and Collin (2001) and Knight, Carlson and Sullivan (2003), who reported higher scores in communicating skills and teamwork for women than for men.

The third question involved analysing students' perceptions regarding the use of the 3D simulation environment on their learning experience. In general, our results showed that the students had a positive perception (82.5\% for Teamwork and 74.3\% for Self-Management) of the effect of the simulation on both competencies and that these digital games provide an excellent online learning environment for students to work in and improve their skills. The students' acceptance of this technology should be used to extend the pedagogical benefits of 3D environments.

In answer to the fourth question, the evaluators shared similar perceptions regarding the island designed by each group. All evaluators reported that the products were more than satisfactory. In fact, each group performed at a score level of notable (within the 4th quartile) in Spanish academic terms, which suggests that this kind of environment enhances the development of tasks related to transferable skills. Gathering information from a more qualitative perspective by interviewing the participating students or through reflective expressions would be useful for understanding the whole process carried out by the groups. In fact, the final presentations provided us with the opportunity to record relevant information about how to manage the project and organise the working group.

\section{Limitations}

One main limitation of this study concerns the referent to be analysed. Despite the large number of variables in the database, it was not possible to obtain information from the system with regard to two of the dimensions that make up the teamwork competence. We did not develop a system that was efficient enough to obtain information about the dimensions of implementation and regulation. However, we did obtain information from all teamwork dimensions when we analysed the island and the end product. It is important to bear in mind that teachers should choose a game style for each content aim. In our case, the game style was a simulation game with learning activities such as playing in virtual worlds.

\section{Conclusion and Future Directions}

The work conducted is helpful for combining the world of education with the possibilities technologies can provide. 3D simulation enables us to mobilize and apply a combination of knowledge, skills and attitudes in specific contexts. It also presents exciting opportunities for designing assessment processes that are active and situated, measure complex student knowledge, and provide rich observations for student learning (Clarke \& Dede, 2010). Moreover, the virtual environment enables the development of curricular competencies that have been previously defined for a particular subject or course. As the activities in the experiment conducted in our study were integrated into the curricula, they were neither parallel nor complementary to the students' training process.

It is also important to take into account the flexibility and portability of the technology used and the proposed teaching sequence. The didactic process could be carried out in different disciplines and at different levels from those in this study. Note also that the participants did not need prior technical training, which reinforces the possibility of extending this experience to any academic domain.

Our research design enables us to analyse the experience in descriptive terms for both the didactic process and the technological environment. This description could serve as a reference for other studies in which the effectiveness and usefulness of these educational environments could be analysed by applying an experimental methodological design. With regard to usability, the Opensim software is a complex tool for designers, teachers and students. Future experiences could incorporate virtual agents (such as historical figures) who could carry out intelligent actions, hold simple conversations or perform simple activities.

According to Sancho et al. (2009), there is not enough evidence of motivation based on novelty to show the usefulness of technology in learning terms. Further research needs therefore to be developed. In line with del Blanco et al. (2012), experiences that encompass the whole education process (design, 
development and assessment) could be extremely useful for education practitioners. The present study could serve as a basis for future work on 3D simulation environments for developing transferable skills.

\section{Acknowledgements}

This research is funded by the national research and development plan of the Spanish Ministry of Science and Innovation. SIMUL@: Evaluation of a Simulation Technological Environment for the Learning of Transversal Competences at University (ref: EDU2008-01479). The project is coordinated by the ARGET research group (ref: 2009SGR596).

\section{References}

Aldrich, C. (2009). Virtual worlds, simulations, and games for education: A unifying view. Innovate: Journal of Online Education, 5(5).

Association of American Colleges and Universities. (2007). College learning for the new global century. Washington DC. Retrieved from http://www.aacu.org/advocacy/leap/documents/GlobalCentury_final.pdf

Barlam, R., Masalles, J., \& Pinya, C. (2010). El projecte Espurn@. Escola catalana, 45(467), 20-22.

Berlanga. A. J., Peñalvo. F. G., \& Sloep. P. B. (2010). Towards Learning 2.0 University. Interactive Learning Environments. 18(3), 199-201.

Bonwell, C., \& Eison, J. (1991). Active learning: Creating excitement in the classroom (AEHE-ERIC Higher Education Report). Washington, D.C.: Jossey-Bass

Burke, S., \& Collin, K. (2001). Gender differences in leadership styles and management skills. Women in Management Review, 16(5), 244-257.

Burkhardt, G., Monsour, M., Valdez, G., Gunn, C., Dawson, M., Lemke, C., ... Martin, C. (2003). In Gauge 21st century skills: Literacy in the digital age. Naperville, IL: North Central Regional Educational Laboratory. Retrieved from http://pict.sdsu.edu/engauge21st.pdf

Cela-Ranilla, J. M., Esteve, V., Marqués L., Gisbert, M., Arias, I., Vaca, B. E., \& Samaniego, G. N. (2011).SIMUL@: 3D spaces to learn generic skills. A pilot study with education students. Proceedings of the 6th International Conference on e-Learning (ICEL), Kelowna, Canada, pp. 324334.

Chang, Y. C., Peng H. Y., \& Chao, H. C. (2010). Examining the effects of learning motivation and of course design in an instructional simulation game. Interactive Learning Environments, 18(4), 319339.

Chickering, A. W., \& Gamson, Z. F. (1991). Seven principles for good practice in undergraduate education. New Directions for Teaching and Learning, 1991(47), 63-69.

Clarke, J., \& Dede, C. (2010). Assessment, technology, and change. Journal of Research on Technology in Education, 42(3), 309-328.

Cuesta-López, S., \& Romero-Santacreu, L. (2013). Improving comprehension by means of 3D visualization tools and other ICTS in specialized scientific educational workshops. Proceedings of INTED 2013, Valencia, Spain, pp. 6572-6577.

Dalgarno, B., \& Lee, M. J. W. (2010). What are the learning affordances of 3-D virtual environments? British Journal of Educational Technology, 41(1), 10-32.

de Freitas, S. (2006). Learning in immersive worlds: A review of game-based learning. London: Joint Information Systems Committee (JISC). Retrieved from http://www.jisc.ac.uk/media/documents/programmes/elearninginnovation/gamingreport_v3.pdf

de Freitas, S., \& Oliver, M. (2006). How can exploratory learning with games and simulations within the curriculum be most effectively evaluated? Computers \& Education, 46(3), 249-264.

del Blanco, Á., Torrente, J., Marchiori, E. J., Martínez-Ortiz, I., Moreno-Ger, P., \& Fernández-Manjón, B. (2012). A framework for simplifying educator tasks related to the integration of games in the learning flow. Educational Technology \& Society, 15(4), 305-318.

European Communities. (2007). Key competencies for lifelong learning: European reference framework. Retrieved from http://ec.europa.eu/dgs/education_culture/publ/pdf/ll-learning/keycomp_en.pdf

Fransen. J., Kirschner, P. A., \& Erkens, G. (2011). Mediating team effectiveness in the context of collaborative learning: The importance of team and task awareness. Computers in Human Behavior, 27, 103-113.

Girvan, C., \& Savage, T. (2010). Identifying an appropriate pedagogy for virtual worlds: A Communal Constructivism case study. Computers \& Education, 55(1), 342-349. 
Grant, M. (2002). Meridian: A middle school computer technologies. Journal a service of NC State University, 5(1).

Gredler, M. (2004). Games and simulations and their relationships to learning. In D. Jonassen (Ed.) Handbook of research on educational communications and technology (pp. 813-828). Mahwah, NJ: Erlbaum.

Green, S. B., \& Salkind, N. J. (2008). Using SPSS for Window and Macintosh: Analyzing and understanding data. Upper Saddle River, NJ: Pearson Prentice Hall.

Herz, J. C. (1997). Joystick nation: How videogames ate our quarters, won our hearts, and rewired our minds. London: Little Brown and Company.

Hirumi, A., Appelman, B., Rieber, L., \& Van Eck, R. (2010). Game design as a collaborative process. TechTrends, 54(5), 38-45

Ibáñez, M. B., García, J. J., Galán, S., Maroto, D., Morillo, D., \& Kloos, C. D. (2011). Design and implementation of a 3D multiuser virtual world for language learning. Educational Technology \& Society, 14(4), 2-10.

Johnson, L., Adams Becker, S., Estrada, V., \& Freeman, A. (2014). NMC Horizon Report: 2014 Higher Education Edition. Austin, Texas: The New Media Consortium.

Kemp, J.W., Livingstone, D., \& Bloomfield, P.R. (2009). SLOODLE: Connecting VLE tools with emergent teaching practice in Second Life. British Journal of Educational Technology, 40(3), 551555.

Khattri, N., \& Sweet, D. (1996). Assessment reform: Promises and challenges. In M. B. Kane, \& R. Mitchell (Eds.) Implementing performance assessment (pp. 1-21). Mahwah (NJ): Lawrence Erlbaum.

Kirriemuir, J. (2004). Literature review in games and learning. Futurelab. Retrieved from http://telearn.archives-ouvertes.fr/docs/00/19/04/53/PDF/kirriemuir-j-2004-r8.pdf

Knight, D., Carlson, L., \& Sullivan, J. (2003, November). Gender differences in skills development in hands-on learning environments. Paper presented at 33rd ASEE/IEEE Frontiers in Education Conference, Boulder, US. Retrieved from http://fie2012.org/sites/fie2012.org/history/fie2003/papers/1447.pdf

Lave, J., \& Wenger, E. (1991). Situated learning. Legitimate peripheral participation. UK: Cambridge University Press.

Leech. N. L., \& Onwuegbuzie. A. J. (2002). A call for greater use of nonparametric statistics. Proceedings of the Annual Meeting of the Mid-South Educational Research Association, Chattanooga, Tennessee. Retrieved from http://www.eric.ed.gov/PDFS/ED471346.pdf

López-Cano, M., Rodríguez-Navarro, J., Rodríguez-Baeza, A., Armengol-Carrasco, M., \& Susín, A. (2007). A real-time dynamic 3D model of the human inguinal region for surgical education. Computers in Biology and Medicine, 37(9), 1321-1326.

Mateo, J. (2000). La evaluación educativa, su práctica y otras metáforas. Barcelona: Horsori.

Meyers, C., \& Jones, T. B. (1993). Promoting active learning: Strategies for the college classroom. San Francisco, CA: Jossey-Bass Publishers.

Ministry of Education of Singapore. (2010). Nurturing our young for the future. Competencies for the 21st century. Singapore. Retrieved from http://www.moe.gov.sg/committee-of-supplydebate/files/nurturing-our-young.pdf.

O’Brien, D., Lawless, K. A., \& Schrader, P. G. (2010). A taxonomy of educational games. In Y. Baek (Ed.) Gaming for classroom-based learning: Digital role playing as a motivator of study (pp. 1-23). New York: IGI Global.

OECD. (2005). The definition and selection of key competencies (DeSeCo). Executive summary. Retrieved from http://www.oecd.org/pisa/35070367.pdf

Palm, T. (2008). Performance assessment and authentic assessment: A conceptual analysis of the literature. Practical Assessment Research \& Evaluation, 13(4). 1-11.

Partnership for 21st Century Skills. (2011). P21 common core toolkit. A guide to aligning the common core state standards with the framework for 21st century skills. Retrieved from http://www.p21.org/storage/documents/P21CommonCoreToolkit.pdf

Pivec, M., Dziabenko, O., \& Schinnerl, I. (2003). Aspects of game-based learning. Proceedings of the 3rd International Conference on Knowledge Management and Knowledge Technologies, Graz, Austria. pp. 216-225.

Prince, M. (2004). Does active learning work? A review of the research. Journal of Engineering Education, 93(3), 223-231.

Proulx. J. (2004). Apprentissage par projet. Sante-Foy: Presses de l'Université du Québec. 
Rodríguez, S. (2000). La evaluación del aprendizaje de los estudiantes. Proceedings of the I Congreso Internacional: Docencia Universitaria e Innovación. Barcelona.

Salas E., Sims D. E., \& Burke C. S. (2005). Is there a 'big five' in teamwork? Small Group Research 36(5), 555-599.

Sancho, P., Moreno-Ger, P., Fuentes-Fernández, R., \& Fernández-Manjón, B. (2009). Adaptive role playing games: An immersive approach for problem based learning. Educational Technology \& Society, 12(4), 110-124.

Savery, J., \& Duffy, T. M. (1996). Problem-based learning: An instructional model and its constructivist framework. In B. Wilson (Ed.) Constructivist learning environments: Case studies in instructional design (pp. 135-148). Englewood Cliffs, NJ: Educational Technology Publications.

Sawyer, B., \& Smith, P. (2008, February). Serious games taxonomy. Paper presented at the Game Developers Conference, San Francisco. Retrieved from http://www.dmill.com/presentations/seriousgames-taxonomy-2008.pdf

SCANS (1991). What work requires of schools. A scans report for America 2000. The Secretary's Commission on Achieving Necessary Skills US Department of Labor. Retrieved from http://wdr.doleta.gov/SCANS/whatwork/whatwork.pdf

Schifter, C. C., Ketelhut, D. J., \& Nelson, B. C. (2012). Presence and middle school students' participation in a virtual game environment to assess science inquiry. Educational Technology \& Society, 15(1), 53-63.

Simpson, R. D. (2003). A search for the complete education: Balancing the needs for survival and fulfilment. Innovative Higher Education, 28(2), 91-105.

Simul@ (2012). SIMUL@: Evaluation of a Simulation Technological Environment for the Learning of Transversal Competences at University (Ref.: EDU2008-01479). Retrieved from http://latedpedago.urv.cat/simula/

Song, L., \& Hill, J. (2007). A conceptual model for understanding self-directed learning in online environments. Journal of Interactive Online Learning, 6(1), 27-42.

Spector, J. M. (2001). An overview of progress and problems in educational technology. Interactive Educational Multimedia, 3, 27-37.

Tuomi-Gröhn, T., \& Engeström, T. (2003). Conceptualizing transfer: From standard notions to developmental perspectives. In T. Tuomi-Gröhn, T. Engeström (Eds.), Between school and work: New perspectives on transfer and boundary-crossing (pp. 19-38). Oxford: Elsevier.

Van Woerkom, M., \& Croon, M. (2009). The relationships between team learning activities and team performance. Personnel Review, 38(5), 560-577.

Whitton, N. (2009). Learning with digital games: A practical guide to engage students in higher education. New York: Routledge.

Wiggins, G., \& McTighe, J. (1998). Understanding by design. Alexandria, Virginia: Merrill Education/ASCD.

Wilson. J. M., Goodman. P. S., \& Cronin. M. A. (2007). Group learning. Academy of Management Review, 32, 1041-1059.

Wren, D. G. (2009). Performance assessment: A key component of balanced assessment system. Virginia Beach: Department of Research, Evaluation, and Assessment.

Zimmerman, B., \& Martínez-Pons, M. (1992) Perceptions of efficacy and strategy use in the selfregulation of learning. In D. Schunk, J. Meece (Eds.), Student perceptions in the classroom (pp. 185207). New York: Routledge.

Corresponding author: José M. Cela-Ranilla, cela.jose@gmail.com

Australasian Journal of Educational Technology (C) 2014

Please cite as: Cela-Ranilla, J., Esteve-Mon, F., Esteve-González, V., \& Gisbert-Cervera, M. (2014). Developing self-management and teamwork using digital games in 3D simulations. Australasian Journal of Educational Technology, 30(6), 634-651. 